logos_i_ethos_2017_(45)_numer specjalny, s. 83-104

DOI: http://dx.doi.org/10.15633/lie.2339

Jakub Synowiec

Uniwersytet Papieski Jana Pawła II w Krakowie

\title{
Umiarkowanie i rozsądek jako cnoty efektywnego altruisty
}

Umiarkowanie i rozsądek to cnoty mające długą i chlubną historię na kartach etycznych rozważań. Niegdyś zalecane przez etyczne autorytety, mogły świadczyć o szlachetności posiadacza, dziś, gdy w życiu publicznym dominuje nastawienie konsumpcjonistyczne, ich realizacja może zostać odebrana raczej jako dowód niskiego statusu. Zarazem w ostatnich latach coraz więcej zamożnych osób decyduje się realizować te cnoty, świadomie ograniczyć

Jakub Synowiec, dr, adiunkt w katedrze etyki na Wydziale Filozoficznym Uniwersytetu Papieskiego Jana Pawła II w Krakowie. Zainteresowania naukowe: argumentacja etyczna, personalizm, filozofia Petera Singera, efektywny altruizm. Wybrane publikacje: Model argumentacji etycznej $w$ etyce personalistycznej Karola Wojtyly i Tadeusza Stycznia, Kraków 2014; Ethics for Everyday Heroes - from Utilitarianism to Effective Altruism, w: „Ethics \& Bioethics" (in Central Europe) 6 (2016) issue 3-4, s. 147-156; Jakie Peter Singer rzuca nam wyzwania, w: Etyka u schyłku drugiego tysiaclecia, Warszawa 2013, s. 215-228. swoją konsumpcję, w prawiając przy tym opinię publiczną w konsternację. W artykule zaprezentuję współczesny ruch filozoficzno-społeczny, który może zatrząść fundamentami konsumpcjonistycznego świata: Efektywny Altruizm. Ruch ten ma swoje korzenie w etyce praktycznej, formułowanej w duchu utylitaryzmu. Celem artykułu jest zrekonstruowanie znaczenia umiarkowania i rozsądku dla powstania i praktyki życia efektywnych altruistów w oparciu o publikacje jego najwybitniejszych przedstawicieli: Petera Singera i Williama MacAskilla. Ponadto zostanie podjęta próba uzasadnienia tezy, że Efektywny Altruizm może być alternatywą dla podejścia konsumpcjonistycznego oraz przyczynić się do praktykowania umiarkowania i rozsądku w życiu publicznym. 


\section{Efektywny altruizm}

Jeszcze w pierwszej dekadzie XXI wieku pojęcie efektywnego altrui$\mathrm{zmu}^{1}$ nie miało jasno określonej denotacji. Po raz pierwszy współczesnego znaczenia nabrało w 2011 roku, gdy powstało Centre for Effective Altruism, ale pojęcie spopularyzował dopiero Singer, który wygłosił wykład na ten temat podczas konferencji z cyklu TED w 2013 roku $^{2}$. Wykład można obejrzeć w internecie w wielu językach, co przekłada się na jego dużą popularność ${ }^{3}$. W tej chwili Efektywny Altruizm to przede wszystkim stale rosnąca społeczność, organizująca się wokół kilku stron internetowych oraz w mediach społecznościowych. Ta różnorodna społeczność próbuje wcielać w życie idee efektywnego altruizmu, ale prowadzi również żywe filozoficzne debaty, co sprawia, że zarówno idea, jak i ruch są zjawiskiem dynamicznym, nieposiadającym ostatecznego kształtu, a przez to trudnym do całościowego ujęcia i teoretycznego usystematyzowania. Opracowania naukowe opisujące efektywny altruizm są na razie stosunkowo nieliczne (chociaż efektywni altruiści bardzo chętnie odwołują się do badań przeprowadzonych w ramach różnych dyscyplin), w języku polskim ukazała się tylko jedna pozycja, ponadto ma ona raczej charakter popularyzatorski niż naukowy, o czym świadczy nawet tytuł: Podręcznik efektywnego altruizmu ${ }^{4}$. W języku angielskim, który jest głównym językiem ruchu, pojawiły się dwie ważne publikacje: Doing Good Better. A Radical New Way to Make a Difference ${ }^{5}$ Williama MacAskilla

1 Efektywny Altruizm pisany wielkimi literami oznacza ruch filozoficzno-społeczny, natomiast pisany małymi literami - filozoficzną ideę.

${ }^{2}$ Historię Efektywnego Alturizmu przytaczam za: Podręcznik efektywnego altruizmu, red. R. Carey, tłum. zbiorowe, Warszawa 2015, s. 12. Konferencje z cyklu TED (Technology, Enviornment, Design) to popularna seria krótkich, kilkunastominutowych wystąpień, których celem jest przedstawienie w jasny i przestępny sposób aktualnych trendów, nowych myśli, idei czy wynalazków. Konferencje są tłumaczone na wiele języków i cieszą się bardzo dużą popularnością wśród internautów.

3 P. Singer, Why and how of effective altruism, https://www.ted.com/talks/peter_singer_the_ why_and_how_of_effective_altruism (17.09.2016).

4 Podręcznik efektywnego altruizmu, dz. cyt.

5 W. MacAskill, Doing Good Better. A Radical New Way to Make a Difference [Czynić dobro lepiej. Nowy, radykalny sposób, żeby zrobić różnicę - tłum. J. S.], London 2015. 
oraz The Most Good You Can Do. How Effective Altruism Is Changing Our Ideas About Living Ethically ${ }^{6}$ Petera Singera. Do nich głównie odwołuję się w tym artykule.

Geneza Efektywnego Altruizmu jest, z punktu widzenia filozofa, budująca. Zawodowi filozofowie - przez swoje trafne diagnozy, sprzeciw wobec schematów myślenia i postępowania, rozwijanie argumentacji etycznej oraz twórcze łączenie wyników badań różnych dziedzin - istotnie przyczynili się do powstania ruchu. Zapleczem intelektualnym dla ruchu i „dawcą idei” jest filozofia praktyczna, budowana w ramach etyki utylitarystycznej, w tym filozoficzna refleksja Singera na temat pomocy biednym, którą rozwija od ponad $40 \mathrm{lat}^{7}$. Ponadto pojawienie się efektywnego altruizmu stało się możliwe dzięki rozwojowi badań naukowych nad metodami pomocy biednym oraz nad racjonalnością człowieka ${ }^{8}$. Nie bez znaczenia były również ostatnie zmiany w krajach najbardziej zamożnych: skokowy wzrost dobrobytu, przyrost świadomości cierpienia innych istot oraz rozwój technologii umożliwiający szybkie przekazywanie środków.

Hasłem, które najkrócej opisuje efektywny altruizm, mógłby być tytuł książki Singera - tyle dobra, ile zdołasz uczynić (The Most Good You Can Do). Zgodnie z tym hasłem efektywny altruizm jest próbą zmiany świata w najlepszy osiągalny. Nie chodzi tylko o poprawianie świata, ale o poprawienie go najlepiej, jak się da, czyli takie skierowanie swoich altruistycznych wysiłków, żeby uzyskać optymalny efekt. Wymóg optymalizacji rezultatu powoduje, że darczyńcy muszą odejść od klasycznych, odruchowych sposobów pomagania. Nasze dobre, emocjonalne odruchy pomocy potrzebującym należy poddać kontroli rozumu. Kontrola ta nie polega jednak jedynie na teoretycznej refleksji, lecz na aplikacji badań

${ }^{6}$ P. Singer, The Most Good You Can Do. How Effective Altruism Is Changing Our Ideas About Living Ethically [Tyle dobra, ile zdołasz uczynić. W jaki sposób Efektywny Altruizm zmienia nasze rozumienie etycznego życia - tłum. J. S.], New Haven-London 2015.

7 Zadanie prześledzenia rozwoju myśli Singera na temat pomocy biednym i zbadanie jej wpływu na powstanie i rozwój Efektywnego Altruizmu zostało częściowo podjęte w artykule: J. Synowiec, Ethics for Everyday Feroes - from Utilitarianism to Effective Altruism, „Ethics \& Bioethics” (in Central Europe) 6 (2016) issue 3-4, s. 147-156.

8 Por. Podręcznik efektywnego altruizmu, dz. cyt., s. 11. 
naukowych celem wybrania najbardziej efektywnej pomocy. Należy ocenić, w oparciu o dowody, które spośród naszych działań przyniosą najwięcej dobra. Nie zawsze da się to dokładnie wyliczyć, nawet posługując się wartościami liczbowymi takimi jak QALY ${ }^{9}$. Mamy raczej, jak zwykle w przypadku kalkulacji utylitarystycznych, do czynienia z pewnymi szacunkami, jednak można chyba zgodzić się z Arystotelesem, że stopień ścisłości właściwy wyliczeniom matematyków czy fizyków nie jest w etyce ani możliwy do osiągnięcia, ani potrzebny ${ }^{10}$.

\section{Dobroczynność pod kontrolą rozumu}

Teoretycy Efektywnego Altruizmu zwracają uwagę, że najczęściej jeżeli już decydujemy się pomagać innym, to zachowujemy się nieracjonalnie. Zupełnie inaczej niż w przypadku inwestycji finansowych. William MacAskill sugeruje, żeby spróbować popatrzyć na pomoc właśnie jak na inwestycję i rysuje przykład firmy, która poszukiwałaby inwestora na ulicy z wykorzystaniem metod, jakie stosują organizacje dobroczynne:

Wyobraź sobie, na przykład, że idziesz ulicą w sąsiedztwie. Atrakcyjna i przerażająco entuzjastyczna młoda kobieta podskakuje przed tobą, blokując ci drogę. Trzyma tabliczkę i ma ubrany podkoszulek z napisem: „olśniewające kosmetyki”. Godzisz się z nią rozmawiać, a ona wyjaśnia, że reprezentuje firmę produkującą kosmetyki, która szuka inwestorów. Tłumaczy ci, jak wielki jest rynek kosmetyków, jak cudowne są produkty, które sprzedają, oraz że firma jest bardzo efektywna, bo 90 proc. wydaje na produkcję, a mniej niż 10 proc. na pensje, dystrybucje i reklamę, zatem czeka cię gigantyczny zysk. Czy byś zainwestował? ${ }^{11}$

9 Quality-adjusted life year - jednostka miary pozwalająca porównać między sobą działania medyczne pod względem ich efektywności, może również służyć do porównywania programów dobroczynnych. Przedłużenie życia zdrowej osoby o jeden rok to 1 QALY. Taki sam wynik uzyskamy również, poprawiając jakość życia o 10 proc. przez 10 lat. Zob. W. MacAskill, Doing Good Better..., dz. cyt., s. 39-44.

${ }_{10}$ Zob. Arystoetels, Etyka nikomachejska, tłum. D. Gromska, Warszawa 2008, s. 79, 1094b.

11 Por. „Imagine, for example, that you're walking down your local high street. An attractive and frighteningly enthusiastic young woman leaps in front of you, barring your way. She clasps a tablet and wears a T-shirt that says 'Dazzling Cosmetics'. You agree to speak to her and she explains 
McAskill nie ma wątpliwości, że nikt rozsądny nie zainwestowałby swoich pieniędzy w oparciu o taką agitację. Inwestowanie pieniędzy zawsze poprzedzają skomplikowane analizy. Dlatego też takie sposoby pozyskiwania inwestorów nie zdarzają się w rzeczywistości. W dobroczynności jest inaczej. Tysiące ludzi wspierają organizacje, o których nigdy nie słyszeli, tylko dlatego, że elokwentny akwizytor zaczepił ich na ulicy, albo ponieważ dostali e-maila, odbyli rozmowę telefoniczną czy zobaczyli reklamę w gazecie. Rzadko podejmują refleksję nad tym, co się później dzieje $\mathrm{z}$ ofiarowanymi pieniędzmi, jakie są skutki ich pomocy ${ }^{12}$. Mało tego, na wsparcie mogą liczyć też rzesze anonimowych żebraków, które korzystają z emocjonalnego odruchu dawania. Kiedy już sięgniemy do portfela, nie zastanawiamy się, ile dobra (i czy w ogóle dobra) temu człowiekowi przyniosą ofiarowane przez nas pieniądze, chcemy raczej, żeby zniknął nam z oczu, ponieważ jego widok jest dla nas oskarżeniem. Kupujemy „za dwa złote” spokój sumienia.

Efektywny altruizm każe przyglądać się różnym formom pomocy oraz programom i w oparciu o dowody wybrać spośród nich najlepsze (nie tylko skuteczne, ale właśnie efektywne, tj. przynoszące najwięcej dobra w przeliczeniu na złotówkę). Pomaganie lokalnym żebrakom w Polsce będzie daleko na tej liście, ponieważ - niezależnie od skuteczności programu - trudno sądzić, że właśnie taki sposób alokacji naszych środków jest wykorzystaniem dostępnych zasobów, które przyniesie światu najwięcej dobra. Pomaganie ubogim w Polsce, nawet przez instytucje,

that she represents a beauty products company that is looking for investment. She tells you how big the market for beauty products is, and how wonderful the products they sell are, and how, because the company spends over $90 \%$ of its money on making the products, and less than $10 \%$ on staff, distribution and marketing, the company is extremely efficient and therefore able to generate an impressive return on investment. Would you invest?" (W. Mac Askill, Doing Good Better..., dz. cyt., s. 1, tłum. J. S.).

12 Singer powołuje się na badania psychologów, z których wynika, że osoby ofiarujące niewielkie sumy nie interesują się efektami, robią to, by poczuć się lepiej. Czasem nie są w stanie dostrzec nawet tego, że koszty przyjęcia ich datku przekraczają jego wysokość (w przypadku wpierania organizacji dobroczynnych bardzo małymi kwotami). Inaczej jest w przypadku osób dających więcej, tutaj można zaobserwować zainteresowanie efektami pomocy. Zob. P. Singer, The Most Good You Can Do..., dz. cyt., s. 5. 
którym udaje się skutecznie zmienić ich los, również na pewno nie będzie najlepszym wyborem dla efektywnego altruisty. Ubodzy w Polsce są relatywnie biedni w stosunku do reszty społeczeństwa i nie można tego bagatelizować, ale jeżeli porównamy ich z osobami żyjącymi w skrajnej biedzie w krajach biednego południa naszej planety, to dojdziemy do wniosku, że są szczęściarzami, dawno nie słyszeliśmy przecież, żeby ktoś w Polsce zmarł z powodu głodu. W Polsce działa wiele instytucji, które pomagają takim osobom i łatwiej im uzyskać wsparcie ze względu na naturalną skłonność każdego z nas do pomagania ludziom nam jakoś bliskim. Efektywny altruista rozważy stosunek skutków i kosztów i na tej podstawie dojdzie do wniosku, że te same pieniądze w mniej zamożnym kraju przyniosą znacznie więcej dobra. Jednak samo pomaganie osobom żyjącym w skrajnej biedzie w kraju rozwijającym się to wciąż zbyt mało, by upewnić się, że pomoc jest skuteczna. Organizacje dobroczynne i programy pomocy różnią się między sobą, i to znacznie. Również w Afryce działają organizacje dobroczynne, które wydają pieniądze nieefektywnie, dlatego prowadzone są badania oceniające skuteczność programów, i tak na przykład dowiedziono, że modne playpumps pogorszyły, zamiast poprawić, dostępność do wody pitnej ${ }^{13}$. Tego typu badania pozwalają nam określić, w co warto inwestować, jakie działanie „wyciśnie” najwięcej dobra z przelanej złotówki. Badania te nie są jednak wolne od kontrowersji, zarówno merytorycznych, jak i etycznych ${ }^{14}$.

Bezpośrednie wsparcie finansowe nie jest jedyną możliwością pomocy. Swego rodzaju cechą charakterystyczną efektywnego altruizmu jest poszukiwanie optymalnej ścieżki kariery dla osób chcących uczynić świat najlepszym. W ramach Efektywnego Altruizmu rozwijane jest szczególne doradztwo zawodowe. Strona 80000hours.org (nazwana tak na cześć szacowanej i zaokrąglonej liczby godzin, jaką większość ludzi spędza

13 Zob. W. Mac Askill, Doing Good Better..., dz. cyt., s. 1-18. Idea playpumps, „pompo-karuzel” napędzanych siłą mięśni bawiących się dzieci, była tak atrakcyjna dla zamożnych społeczeństw, że pozwoliła zgromadzić znaczne fundusze.

$14 \mathrm{~W}$ artykule nie ma miejsca na rozwijanie tego zagadnienia, temat ten został częściowo opracowany m.in. w książce: A. Leszczyński, Eksperymenty na biednych. Polityczny, moralny i ekonomiczny spór o to, jak pomagać skutecznie, Warszawa 2016, s. 146-158. 
w pracy) jest portalem, z pomocą którego można wybrać motywowaną etycznie karierę. Jest wiele uzasadnionych etycznie opcji, z których należy wybrać właściwą dla swoich predyspozycji. Jednym z polecanych wyborów jest kariera umożliwiająca duże zarobki. Duże zarobki pozwalają ofiarować znaczne sumy, co - w wypadku wspierania najefektywniejszych organizacji - oznacza zrobienie dużej ilości dobra. Peter Singer przedstawia przykład młodego człowieka, który na podstawie utylitarystycznej kalkulacji obliczył, że więcej dobra uczyni, wybierając karierę w sektorze bankowości zamiast akademickiej. Według szacunków Singera pozwoliło to mu w ciągu pierwszego roku lub dwóch przekazać kwotę zbliżoną do tego, co mógłby ofiarować przez całe życie, gdyby zdecydował się oddawać 10 proc. swojej pensji profesorskiej ${ }^{15}$. Oczywiście to oznacza, że wspomniany efektywny altruista posiadał zdolności do tego, by objąć taką posadę. Jeżeli przejawiamy zdolności do pracy jako naukowiec, taka ścieżka kariery może okazać się nawet lepsza niż szukanie najlepiej płatnej posady. Opracowanie nowej szczepionki czy terapii, nawet jeśli nasz wkład w to będzie niewielki, może przynieść daleko więcej dobra niż ogromna ilość zarobionych pieniędzy. Nie można również nie doceniać kariery polegającej na prowadzeniu badań nad skutecznością działalności dobroczynnej, których wyniki będą miały wpływ na alokację środków pochodzących od darczyńców.

Tradycyjne „etyczne kariery”, takie jak pracownik organizacji dobroczynnej czy służby zdrowia, nie są dla efektywnych altruistów oczywistym wyborem. Wiele osób nadaje się na pracownika organizacji dobroczynnej, więc jeżeli możemy wybrać pracę, dzięki której przekażemy dość pieniędzy, by zatrudnić kilku, to już samo to wskazuje, że jest to opcja lepsza. Lekarze w Europie zarabiają dużo, więc ich datki mogą być znaczne, ale sama profesja niekoniecznie musi oznaczać, że ocalą więcej istnień, niż osoby pracujące w innych zawodach. Wiele zależy od specjalizacji, a także miejsca pracy - w krajach najuboższych każdy dodatkowy lekarz robi ogromną różnicę. Geneza ruchu pokazuje, że warta rozważenia jest również kariera filozofa. Filozofowie mogą skutecznie argumentować na rzecz

15 Zob. P. Singer, The Most Good You Can Do..., dz. cyt., s. 3-4. 
efektywnego altruizmu, zachęcać ludzi do etycznego życia, kształtować ich postawy, pomagać im, aby stali się orędownikami efektywnego altruizmu ${ }^{16}$. Wybierając ścieżkę kariery, musimy zastanowić się, która z nich może przynieść, w naszym wydaniu, najwięcej dobra.

Efektywni altruiści zastanawiają się również, jakie wybrać cele do realizacji, czyli uporanie się z którymi problemami potencjalnie przyniesie najwięcej dobra. Obecnie za problemy rekomendowane efektywnym altruistom uważane są: ubóstwo na świecie, cierpienie zwierząt, jakie powoduje chów przemysłowy, i zabezpieczanie istnienia rodzaju ludzkiego ${ }^{17}$, jednak ruch jest otwarty na inne cele, o ile zostaną przedstawione argumenty przemawiające za tym, że ich realizacja przyniesie najwięcej dobra w stosunku do poniesionych kosztów. Dyskusje na ten temat są bardzo żywe. Zasadniczo wykorzystuje się trzy kryteria, które pozwalają na wybranie priorytetowych obszarów działania: zasięg (scale), czyli to, na ile istot objętych moralną kalkulacją wpływa dany problem, stopień zainteresowania (neglectedness), czyli to, ile środków przeznacza się, aby rozwiązać problem, oraz wykonalność (tractability), czyli to, czy problem w ogóle da się rozwiązać i czy alokowane środki coś zmienią. Efektywni altruiści nie zajmują się kwestiami, których zasięg jest mały, takimi jak wsparcie lokalnych wspólnot czy wspieranie organizacji ratujących bezdomne zwierzęta. Programowo unikają też działalności filantropijnej, która nie przynosi redukcji cierpienia, takiej jak wspieranie sztuki. Z ogromnych problemów wybierane są te, nad którymi tradycyjne organizacje dobroczynne pochylają się rzadko albo wcale (likwidacja skrajnej biedy, cierpienie zwierząt na farmach przemysłowych czy kwestie egzystencjalnego zagrożenia ludzkości). Nie wszystkie problemy, które mają duży zasięg, cieszą się zarazem brakiem zainteresowania, na przykład szczepienia czy walka $\mathrm{z}$ efektem cieplarnianym to problemy, które przyciągnęly uwagę wielu osób, a programy im dedykowane groma-

\footnotetext{
$16 \mathrm{~W}$ artykule Ethics for Everyday Heroes - from Utilitarianism to Effective Altruism, dz. cyt., s. 147-156 argumentuję, że popularyzacja etycznego myślenia to być może najlepsza strategia, jaką mogą przyjąć osoby zarabiające w krajach średnio zamożnych, jak Polska.

17 Por. Podręcznik efektywnego altruizmu, dz. cyt., s. 25.
} 
dzą znaczne środki, dołączenie do nich niewiele zatem zmienia. Istnieją również problemy o dużym zasięgu, na których rozwiązanie przeznacza się jednakże niewielkie środki, bowiem w świetle obecnej wiedzy żadna suma pieniędzy czy ilość poświęconego czasu nie czynią prawdopodobnym ich pokonania. MacAskill podaje jako przykład problem starzenia się, który odpowiada za ok. 2/3 zgonów na świecie, a jednak tylko kilku badaczy się z nim mierzy, bowiem dotychczasowe wyniki badań wskazują, że nie ma nadziei na rozwiązanie tego problemu ${ }^{18}$.

Zastosowanie tych kryteriów pozwoliło szwedzkiemu filozofowi Nickowi Bostromowi w przekonujący sposób argumentować, że światowe zasoby finansowe przeznaczone na cele dobroczynne należałoby kierować na badania zmierzające do ocalenia ludzkości przed możliwą katastrofą. Liczebność przyszłych ludzi będzie tak wielka, że zdaniem tego filozofa udział w ocaleniu ich (przez powstrzymanie zagłady inteligentnego życia na ziemi) przeważa dowolną pomoc, jaką jesteśmy w stanie nieść ludziom współczesnym ${ }^{19}$. Jest to kwestia, na którą nie przeznacza się wiele środków, choć wydaje się, że postęp jest możliwy do osiągnięcia, zwłaszcza że autodestrukcyjne możliwości człowieka znacznie rosną, $\mathrm{a}-\mathrm{z}$ drugiej strony - powstrzymanie antropogenicznych katastrof wydaje się być prostsze niż np. manipulacja ruchem ciał niebieskich. Choć wielu współczesnych filozofów uważa ludzkość za największy problem naszej planety, efektywni altruiści doceniają wartość inteligentnego życia i pośród priorytetów wymieniają również ocalenie ludzkości, także przed nią samą.

Efektywny Altruizm nie jest pierwszą propozycją optymalizacja świata, jaką proponowali filozofowie. Próba tworzenia raju na ziemi zawsze jest obarczona ryzykiem spektakularnej porażki. Dość wspomnieć nieudane próby Platona czy twórcy pojęcia altruizm: Augusta Comte’a, zaś optymalizacja świata realizowana przez niektórych kontynuatorów myśli Marksa do dziś budzi grozę. W tej chwili Efektywny Altruizm wydaje się

18 Zob. W. MacAskill, Doing Good Better..., dz. cyt., s. 226.

19 Zob. N. Bostrom, Existential Risk Prevention as Global Priority, „Global Policy” 4 (2013) issue 1, s. 15-31. 
wartościowy choćby dlatego, że proponuje alternatywny do konsumpcjonistycznego model życia, nastawiony na pomoc innym, a nie tylko zaspokajanie swoich, coraz rozleglejszych, potrzeb. Co więcej, efektywny altruizm zachęca do objęcia troską nie tylko ludzi w potrzebie, ale wszystkie istoty zdolne odczuwać ból oraz... przyszłe istoty tego rodzaju. Jest to zatem jedna $\mathrm{z}$ bardziej wymagających teorii etycznych.

Ponieważ mamy do czynienia z ideą filozoficzną, sformułowaną przez zawodowych filozofów, efektywny altruizm od samego początku jest przedmiotem kontrowersji. Zmusza to jego zwolenników do intelektualnego wysiłku doskonalenia argumentów przemawiających na rzecz tego stanowiska. Część komentatorów zwraca uwagę na słabości, jakie Efektywny Altruizm dziedziczy po utylitaryzmie, szczególnie nieprecyzyjność szacunków skutków naszych działań, zwłaszcza w dalekiej perspektywie. Zarzut ten na pewno pozwala kwestionować obliczenia dotyczące efektów naszej pomocy dla przyszłych ludzi ${ }^{20}$.

Można również na Efektywny Altruizm spojrzeć przez pryzmat logiki świata konsumpcji i uznać, że jest to kolejna forma "kupowania sobie” czegoś fajnego. Zwłaszcza, że teoretycy efektywnego altruizmu trochę do tego zachęcają, podkreślając głównie finansowy wymiar pomocy. MacAskill sugeruje nawet, że można w pewnym sensie wyrównać swój negatywny wpływ na środowisko dzięki wspieraniu organizacji, które z nim walczą, i na przykład skompensować szkodliwość potężnego silnika przez dotację dla organizacji walczącej z efektem cieplarnianym $^{21}$. I choć MacAskill wprost pisze, że nie można w ten sposób kompensować cierpienia, łatwo można sobie wyobrazić, że efektywny altruizm może stać się nowoczesną formą „kupowania odpustów” lub

\footnotetext{
20 Temat obowiązków wobec przyszłych ludzi jest dla filozofów fascynujący i budzi zainteresowanie wśród efektywnych altruistów. Na ten temat powstały liczne opracowania naukowe, klasyczne już są rozważania Dereka Parfita w książce Racje i osoby, Warszawa 2012, zwłaszcza s. 403-410. W Polsce niedawno dyskusję próbował usystematyzować Tomasz Żuradzki w artykule Granice troski o przyszłe pokolenia, „Diametros” 26 (2010), s. 206-225, a także Wojciech Lewandowski w książce Przyszłość i odpowiedzialność. Problem uzasadnienia odpowiedzialności za przyszłe pokolenia we wspótczesnej etyce, Lublin 2015.

${ }^{21}$ Zob. W. MacAskill, Doing Good Better..., dz. cyt., s. 174.
} 
przynajmniej kupowania poczucia, że jest się dobrym, wartościowym człowiekiem, bez konieczności całościowego patrzenia na swoje życie. Pojawia się również pytanie, na ile efektywny altruizm da się pogodzić z innymi niż utylitarystyczny światopoglądami. Chociaż ruch na każdym kroku podkreśla swoją otwartość i wiele jego postulatów współgra z katolicką nauką społeczną ${ }^{22}$, pierwsze skrzypce odgrywają w nim utylitaryści, a projekty takie jak Christians and Effective Altruism nie przyciągają wielkiego zainteresowania. Tymczasem lansowana przez utylitarystów koncepcja zmiany świata zakłada swoiste, właściwe dla tego nurtu rozumienie pojęcia dobra, dające się właściwie zdefiniować jako usunięcie cierpienia, co z punktu widzenia innych stanowisk etycznych jest rozumieniem redukcjonistycznym. Dyskusja nad tym kluczowym dla ruchu terminem mogłaby otworzyć go na inne szkoły etyczne, zwłaszcza na myśl inspirowaną chrześcijaństwem, i uczynić bardziej uniwersalnym.

Kilku filozofów argumentowało przeciw efektywnemu altruizmowi w reakcji na książkę Singera. Krytykę tę zebrał i w przekonujący sposób odparł Jeff McMahn w swoim artykule Philosophical Critiques of Effective Altruism $^{23}$. Można sądzić, że najbliższe lata okażą się przełomowe. Jeżeli Efektywny Altruizm będzie w stanie w przekonujący sposób wykazać, że ogromne środki, które przekierował do wybranych organizacji dobroczynnych, rzeczywiście pozwoliły wycisnąć więcej dobra z każdej oddanej złotówki, to będzie to wielki sukces, jeżeli jednak nie, to grozi mu los innych wielkich inicjatyw, które na chwilę wzbudziły nadzieję na odmianę świata, jak OLPC ${ }^{24}$ czy wioski milenijne.

22 O możliwości współpracy między chrześcijanami i efektywnymi altruistami zob. A. Liberman, Effective Altruism and Christianity: Possibilities for Productive Collaboration, „Essays in Philosophy” 18 (2017) issue 1, s. 2-24.

23 J. McMahan, Philosophical Critiques of Effective Altruism, „The Philosophers' Magazine” 2016 issue 73, s. 92-99.

${ }^{24}$ OLPC (One laptop per child) program walczący z wykluczeniem informatycznym w mniej zamożnych społeczeństwach. Założeniem była produkcja i dystrybucja tanich, trwałych i prostych w obsłudze urządzeń przenośnych. 


\section{Rozsądek w Efektywnym Altruizmie}

W tej części artykułu spróbuję wykazać, że rozsądek jest kluczową cnotą dla efektywnego altruisty oraz że Efektywny Altruizm jest w pewnym sensie odpowiedzią na postulaty rozsądku w kwestii dobroczynności. W języku potocznym rozsądek jest pojęciem budzącym generalnie pozytywne skojarzenia, a zarazem wieloznacznym i rozmytym, dodatkowo filozofowie zaproponowali ujednoznacznienia tego terminu, które się ze sobą nie pokrywają. Słownik języka polskiego definiuje rozsądek jako „zdolność trafnego oceniania sytuacji i odpowiadającego tej ocenie zachowania się" 25 , czyli zdolność do rozumowania, trafnej oceny i adekwatnego wyboru działania. Takie rozumienie rozsądku wydaje się odpowiadać powszechnemu użyciu tego terminu w języku polskim.

W filozofii zaproponowano wiele możliwości rozumienia pojęcia „rozsądek”, niebagatelne znaczenie odgrywa też rozróżnienie rozsądku i rozumu w filozofii Kanta ${ }^{26}$. Inne popularne ujednoznacznienie tego terminu to common sense, odpowiada ono, jak się wydaje, polskiemu pojęciu zdrowego rozsądku: pewnego zespołu przeświadczeń, który dzielą i uważają za słuszne wszyscy ludzie ${ }^{27}$. Rozważając jednak rozsądek jako cnotę efektywnego altruisty, w naturalny sposób przywołujemy filozofa, który spopularyzował pojęcie cnoty w znaczeniu etycznym: Arystotelesa. Umieszcza on rozsądek (phronesis) pośród cnót dianoetycznych, właściwych rozumnej części duszy. W Etyce nikomachejskiej można znaleźć kilka określeń precyzujących jego rozumienie rozsądku. Filozof twierdzi na przykład, że rozsądek jest „trwałą dyspozycją do działania opartego na trafnym rozważeniu tego, co dla człowieka jest dobre lub złe"28, a ludzie rozsądni potrafią „,dojść do tego, co jest dobre dla nich samych i dla ludzi w ogóle, przypisujemy go [rozsądek] też tym, którzy biegli są w sztuce

\footnotetext{
${ }_{25}$ Por. Rozsadek, w: Słownik języka polskiego PWN, http://sjp.pwn.pl/slowniki/rozs\%C4\%85dek. html (18.09.2016).

${ }^{26}$ Por. J. Hartman, Rozsądek, w: Stownik filozofii, red. J. Hartman, Kraków 2004, s. 194.

27 J. Hartman, Rozsądek, w: Stownik filozofii, dz. cyt., s. 194.

28 Arystoteles, Etyka nikomachejska, dz. cyt., s. 197, 1140b.
} 
zarządzania domem i państwem”29, wreszcie „rozsądek jest trwałą dyspozycją do działania opartą na trafnym rozważeniu tego, co jest dobre dla ludzi”" ${ }^{\prime 30}$. Te myśli Arystotelesa wydają się współgrać z zaleceniami dla praktyki życia efektywnych altruistów, którzy - nastawiając się na cel: optymalizację świata - powinni być w stanie trafnie rozważyć, co jest dobre dla innych istot. Co więcej, realizuje się to między innymi przez dobre zarządzanie domem i państwem.

Problematyczne dla efektywnych altruistów mogłoby być skoncentrowanie się Arystotelesa na „dobru ludzi w ogóle” z pominięciem innych istot, zwłaszcza zwierząt, o które troska odgrywa w ruchu duże znaczenie. Trzeba jednak mieć na uwadze, że nawet dziś mówiąc „ludzie”, mamy z pewnością na myśli inny zbiór istot, niż miał Arystoteles i jego starożytni czytelnicy. Z tego powodu uprawnione wydaje się przyjęcie, że rozsądek to trwała dyspozycja do działania opartego na trafnym rozważeniu tego, co jest dobre dla istot, które bierzmy pod uwagę w naszych moralnych rozważaniach". Taka definicja nie wyklucza a priori żadnych istot ze zbioru tych, o których dobro należy się troszczyć.

Warto podkreślić, że takie rozumienie rozsądku oznacza, że nie chodzi tylko o pewną techniczną sprawność polegającą na umiejętnym dobieraniu środków do określonego celu. Chodzi o szczególny cel, o to, co jest „dobre dla ludzi”, pojawia się tu odniesienie do dobra i zła, zatem rozsądek ma niewątpliwie rys etyczny.

Refleksję nad znaczeniem rozsądku dla efektywnych altruistów warto zaczać od zauważenia, że zastosowany do „nieefektywnego altruizmu”, czyli tradycyjnych form pomocy, raczej zniechęcał do dawania w ogóle. Ogromna liczba skandali związanych z organizacjami pomocowymi czy reportaży przygotowanych przez media sprawiła, że zaufanie do organizacji dobroczynnych czy przekonanie o autentyczności postaw osób proszących o pomoc znacznie zmalały. Podważyło to przekonanie, że pomagając w ten sposób, robimy coś dobrego. Dość powiedzieć, że wiele osób jest zdania, że lepiej wrzucić pieniądze do kapelusza komuś, kto

29 Arystoteles, Etyka nikomachejska, dz.cyt., s. 197, 1140b.

30 Arystoteles, Etyka nikomachejska, dz. cyt., s. 198, 1140b. 
„uczciwie” zbiera na piwo, niż komuś, kto twierdzi, że zbiera na chleb. $\mathrm{Z}$ intelektualnego namysłu nad pomocą wzięły się przecież radykalne głosy wielu filozofów i badaczy, podważające sens pomocy krajom rozwijającym się. Echo tych głosów jest obecnie powszechne słyszalne w sferze publicznej i w pewnym stopniu zagłusza wyrzuty sumienia związane z nieudzieleniem pomocy. Brzmią one mniej więcej tak: „nierozsądnie jest pomagać, ponieważ nie potrafimy trafnie ocenić, co się faktycznie dzieje z naszą pomocą, jakie są jej efekty”, a nawet: „efekty naszej pomocy są złe/szkodzą beneficjentom pomocy"31.

Potrafimy jednak określić warunki, które musi spełnić pomoc, aby była zgodna $\mathrm{z}$ rozsądkiem. Zasadniczym warunkiem wydaje się możliwość analizy wyników tej pomocy. Ta intuicja jest obecna choćby w powszechnych w przestrzeni publicznej wskazówkach, by zamiast dawać pieniądze „na chleb”, obdarowywać jedzeniem osoby motywujące swoją prośbę doskwierającym głodem - pieniądze można łatwiej wykorzystać niezgodnie z przeznaczeniem.

Analiza wyników pomocy pozwala ocenić jej efektywność, czyli stosunek kosztów do osiągniętych efektów. Efektywny Altruizm jest w tym wypadku owocem rozsądku, jako że propaguje opartą na dowodach i analizach selekcję celów i metod pomocy, jak i możliwość oceny skuteczności organizacji pomocowych, dokonywaną w oparciu o fakty i analizy o charakterze raczej matematycznym niż emocjonalnym. Aby uczynić zadość wymaganiom rozsądku, organizacje pomocowe muszą się stać wzorem instytucji finansowych - transparentne. Etyka praktyczna podąża w tym przypadku za standardami ekonomii praktycznej, ponieważ w obu przypadkach kluczowe znaczenie ma efektywna alokacja środków finansowych.

Świadectwa życia efektywnych altruistów oraz refleksja teoretyków ruchu wskazują, że rozsądek zachęca do kształtowania w sobie cnoty

${ }^{31}$ Krytykę dobroczynności znaleźć można np. w książce: W. Easterly, The White Man’s Burden. Why the West's Efforts to Aid the Rest Have Done so much Ill and so Little Good, New York 2006. Poważne argumenty wskazujące na nieefektywność pomocy przedstawia Adam Leszczyński w książce: Eksperymenty na biednych. Polityczny, moralny i ekonomiczny spór o to, jak pomagać skutecznie, Warszawa 2016. 
umiarkowania. Patrząc na postulaty praktyki życia codziennego formułowane przez efektywnych altruistów, można powiedzieć, że zalecanie zachowania umiaru i praktykowanie rozsądku są ze sobą ściśle związane.

\section{Umiarkowanie w Efektywnym Altruizmie}

W tej części artykułu staram się wykazać, że cnota umiarkowania pojawia się w praktyce życia efektywnego altruisty i jest wynikiem zastosowania rozsądku do najważniejszego zasobu, jakim dysponujemy: naszego życia. Co więcej, wydaje się, że umiarkowanie jest jedną z podstawowych dróg do uczynienia świata najlepszym z możliwych, a więc i do osiągnięcia szczęścia. Nie jest to pomysł nowy, umiarkowanie należy do cnót kardynalnych i jest rozumiane jako cnota, „która pozwala opanować dążenie do przyjemności i zapewnia równowagę w używaniu dóbr stworzonych. Zapewnia panowanie woli nad popędami i utrzymuje pragnienia w granicach uczciwości" (Katechizm Kościoła Katolickiego, nr 1809). Wielu filozofów zalecało umiar, powściągliwość, brak przesady, samoograniczenie własnych potrzeb, kontrolę nad popędami, jako drogę do szczęścia, zarówno w immanentnych, jak i transcendentnych koncepcjach szczęścia.

W koncepcji Arystotelesa każda z cnót jest pewnego rodzaju umiarem, słuszną miarą między sobie właściwymi skrajnościami, nadmiarem i niedostatkiem. Co więcej, według Arystotelesa jest to właściwa miara ze względu na nas, „którą określa rozum i to w taki sposób, w jaki by ją określił człowiek rozsądny" ${ }^{32}$. Wydaje się zatem, że przynajmniej w myśli Arystotelesa, zachowanie umiaru można powiązać z rozsądkiem.

Szczególnym przypadkiem zachowania umiaru jest cnota umiarkowania. Arystoteles odnosi ją do przyjemności, umiarkowanie jest słusznym środkiem między niewrażliwością a rozwiązłością ${ }^{33}$. O człowieku umiarkowanym Stagiryta pisze: „pragnie natomiast w sposób umiarkowany i właściwy wszystkich rzeczy przyjemnych, które przyczyniają się

32 Arytsoteles, Etyka nikomachejska, dz.cyt., s. 113, 1107a.

${ }^{33}$ Zob. Arystoteles, Etyka nikomachejska, dz. cyt., s. 115, 1107b. 
do zdrowia i dobrego samopoczucia, a także innych przyjemności, o ile nie stanowią przeszkody w osiągnięciu wspomnianych właśnie lub nie są niezgodne z tym, co moralnie piękne i nie przekraczają jego środków majątkowych" ${ }^{34}$. Dalej podkreśla, że człowiek umiarkowany postępuje w ten sposób, bo kieruje się słuszną oceną. Wydaje się, że te rozważania Arystotelesa są bliskie postulatom efektywnego altruizmu. Namysł nad tym, co słuszne, prowadzi do zmian w życiu. Zmiany te nie oznaczają jednak zrezygnowania z przyjemności w ogóle ${ }^{35}$, efektywni altruiści nie są zachęcani do „rozdania wszystkiego, co mają”, ale raczej do tego, by czerpać radość z życia, ale również podzielić się swoimi dobrami z najbardziej potrzebującymi. Wydaje się, że korzystanie z życia bez uwzględniania własnego udziału w czynieniu świata najlepszym jest sprzeczna $\mathrm{z}$ „tym, co moralnie piękne”. Zarazem, efektywny altruista powinien unikać drugiej skrajności, całkowitego odcięcia się od przyjemności, gdyby uczyniło to jego życie nieszczęśliwym ${ }^{36}$.

Singer bezpośrednio zaleca umiarkowanie, już na samym początku książki The Most Good You Can Do zaznacza, że efektywny altruista „żyje w sposób umiarkowany (modestly)" ${ }^{\text {37 }}$ i umiarkowanemu życiu poświęca cały trzeci rozdział tej książki. Nawet niezbyt dobrze zarabiające osoby, dzięki praktykowaniu umiarkowania, zmniejszają swoją przyjemność tylko w niewielkim stopniu, a mogą w stopniu znacznym przyczynić się do szczęścia innych - niezrealizowane, a nie niezbędne przyjemności osób żyjących w zamożnych społecznościach mogą (jeśli zaoszczędzone pieniądze zostaną przekazane odpowiednim organizacjom) przywrócić wzrok czy uratować życie. Co więcej, dzielenie się z innymi, robienie tyle dobra, ile się da, nadaje sens życiu i jest drogą do szczęścia.

34 Arystoteles, Etyka nikomachejska, dz.cyt., s. 145, 1119a.

35 Singer twierdzi, że gdyby ludzie byli w pełni racjonalni i potrafili bezstronnie porównać interesy swoje i innych, to poświęciliby wszystko, co ma mniejszą wartość niż życie ludzkie, aby ratować ludzi ze skrajnej biedy. Jednak domaganie się takiej postawy przyniosłoby skutki odwrotne od zamierzonych - raczej zniechęciłoby do pomocy. Dlatego postuluje przyjęcie standardów, na które ludzie są gotowi. Zob. P. Singer, Życie, które możesz ocalić, tłum. E. De Lazari, Warszawa 2011, s. 231-265.

36 P. Singer, The Most Good You Can Do..., dz. cyt., s. 29-30.

37 P. Singer, The Most Good You Can Do..., dz. cyt., s. 4. 
Patrząc na współczesny świat, można odnieść wrażenie, że postulat zachowania umiaru w odniesieniu do przyjemności nie trafia do serc i rozumów ludzi, którzy nie są do tego „zmuszeni” przez powody ekonomiczne i społeczne. W konsumpcjonistycznym modelu życia można postrzegać umiar - rozumiany jako powściągliwość w nabywaniu nowych dóbr i usług, w realizowaniu swoich pragnień - jako coś, co staje na drodze do szczęścia.

Propagując umiarkowanie, efektywny altruizm jest zaprzeczeniem konsumpcjonizmu rozumianego po prostu jako materialistyczny hedonizm, czyli nieuzasadnione zdobywanie dóbr materialnych i usług i ocenianie jakości/sensu życia według stanu posiadania. Joanna Mysona Byrska, opisując współczesne tendencje w życiu publicznym, pisze: „świat konsumpcji wartościuje i ocenia według dóbr materialnych, którymi dysponuje jednostka. Więcej znaczy lepiej, czyli bardziej wartościowo" ${ }^{38}$, w innym miejscu: „Największa jest jakość życia konsumenta, który może konsumować dobra drogie, w dużych ilościach (częste zmiany przedmiotów, którymi się otacza) i nadmiar (resztki) wyrzuca"39. Zaprzeczeniem tej logiki jest postawa efektywnego altruisty. Zastosowanie rozumu do danych doświadczenia, takich jak różnica w poziomie zamożności między społeczeństwami krajów bogatych i biednych czy zmiana jakości życia innych, jaką można osiągnąć, poświęcając relatywnie niewiele, połączone z uznaniem za słuszną zasady, że należy optymalizować świat, prowadzi do odrzucenia „magicznego świata konsumpcji” na rzecz odartego z magii, ale pociągającego mocą logicznej konieczności świata umiarkowania.

Urzeczywistnienie cnoty umiarkowania w życiu codziennym efektywnego altruisty oznacza ograniczenie „chcenia” do kluczowych potrzeb i świadome poszukiwanie tych sposobów zaspokojenia naszych potrzeb, które dadzą najlepszy efekt w stosunku do kosztów. Zamiast jechać na wakacje do egzotycznych miejsc i zrobić zdjęcia, które zrobią wrażenie

38 J. Mysona Byrska, Odpowiedzialność konsumenta w świecie konsumpcji, w: Społeczna odpowiedzialność gospodarki. Perspektywa interdyscyplinarna, red. S. Fel, Lublin 2014, s. 151.

39 J. Mysona Byrska, Wplyw wartości świata konsumpcji na sferę publiczną, Filo-Sofija" 15 (2015) nr 29 (2/I): Z problemów współczesnej filozofii, s. 107. 
na znajomych z portali społecznościowych, efektywny altruista jedzie na wakacje, aby odpocząć, ale szuka sposobów generujących jak najmniej kosztów. Stojąc w obliczu zakupienia samochodu, efektywny altruista nie nabędzie potężnego SUV-a, którego zakup najczęściej uzasadniony jest jedynie przez próżność, lecz wybierze samochód adekwatny do swoich rzeczywistych potrzeb, czyli taki, który zapewni mu sprawne realizowanie określonych celów. Umiarkowanie w realizacji potrzeb motoryzacyjnych ma znaczenie także dla „przyszłych ludzi”. Zamiast wyrzucać rzeczy i wymieniać je na nowe, efektywny altruista używa ich tak długo, jak długo są sprawne. Nawet wtedy, gdy już nie są modne, mają za małą rozdzielczość czy gdy najnowsze aplikacje nie dają się na nich uruchomić. Umiarkowanie efektywnego altruisty przejawia się także w sferze kulinarnej, może polegać na zrezygnowaniu z mięsa, zwłaszcza pochodzącego z ferm przemysłowych (wkład w redukcję cierpienia zwierząt), albo komponowaniu posiłków tak, żeby dostarczały raczej wartości odżywczych niż wrażeń estetycznych i smakowych. Konsekwencją umiarkowania może być również niemarnowanie żywności, wynikające z tego, że efektywny altruista stara się efektywnie wykorzystać produkty spożywcze, które nabył.

Perfekcjonistyczna etyka Arystotelesa widziała w zachowaniu umiaru drogę do zdobycia cnót, a więc szczęścia. W efektywnym altruizmie celem zachowania umiaru również jest szczęście, ale jak największej liczby branych pod uwagę istot, a nadto przez wielu rozumiane hedonistycznie. Umiarkowanie przejawia się w obszarach, które łączą się możliwością zachowania środków, posłużą optymalizacji świata oraz tych, w których wpływamy na życie innych istot, także przyszłych pokoleń. Ponieważ motywem realizacji umiarkowania jest chęć przekazania dodatkowych środków finansowych w celu uczynienia świata najlepszym, cnota ta ma w efektywnym altruizmie wymiar ekonomiczny i w zasadzie oznacza oszczędność. Nie jest to jednak oszczędność motywowana chęcią zgromadzenia funduszy na bardziej kosztowne przyjemności, lecz forma przekroczenia prymatu własnego ,ja”, samoograniczenie swoich potrzeb, aby pomóc innym realizować ich bardziej podstawowe potrzeby. Efektywny altruista rozumie, że więcej dać można wtedy, kiedy się więcej ma. To 
motywuje zarówno do wytężonej pracy, jak i do oszczędzania. I te zaoszczędzone pieniądze przeznacza na pomoc potrzebującym, samemu wciąż mogąc cieszyć się z życia ${ }^{40}$. Radość z życia nie wynika tu z przyjęcia umiarkowania za obiektywnie słuszną postawę, lecz z poczucia, że zmienia świat na lepsze, a umiarkowanie - dobrowolne wyrzeczenie się niektórych przyjemności - jest w tym wypadku środkiem.

\section{W stronę rehabilitacji cnót}

Arystoteles przekonująco argumentował, że zdobywanie dóbr materialnych nigdy nie zaspokoi człowieka w pełni, choć pewne ich minimum jest niezbędne jako środek do osiągnięcia szczęścia ${ }^{41}$. Podobnie myśli teoretyk efektywnego altruizmu, Singer, który od wielu lat zwraca uwagę, że konsumpcjonistyczny styl życia, szukanie szczęścia w egoistycznym spełnianiu własnych pragnień nie przynosi ludziom tego, co obiecuje. Nie daje szczęścia, raczej coś odwrotnego, nawet tym najbogatszym. Według tego filozofa prawdziwe szczęście może dać jedynie życie etyczne, skierowane na dobro innych istot ${ }^{42}$. Praktykujący efektywny altruizm potwierdzają to ${ }^{43}$. Kiedy zaczęli żyć z myślą o innych, samoograniczać się dla celów wykraczających poza egoistycznie rozumiany interes, doświadczyli poczucia szczęścia i spełnienia, jakiego dotąd nie znali. Dobroczynność może kojarzyć się z odbieraniem czegoś sobie, żeby dać innym, zatem raczej z cierpieniem niż szczęściem. Efektywny Altruizm to działania, w których obie strony zyskują. Może dlatego efektywne organizacje pomocowe otrzymują z roku na rok coraz więcej pieniędzy. Strona givewell.org podaje, że w roku 2015 rekomendowane przez nią

40 Zastrzeżenie, że należy przy tym cieszyć się z życia, jest bardzo ważne dla idei efektywnego altruizmu. Pojawiają się w nim jednak tendencje skrajne, np. pytanie o to, czy efektywny altruista może mieć dzieci, skoro generują one koszty. Więcej o tym, jak powinien wyglądać umiar w życiu efektywnego altruisty: P. Singer, The Most Good You Can Do..., dz. cyt., s. 23-37.

41 Por. Arystoteles, Etyka nikomachejska, dz.cyt., s. 83, 1096a.

42 Por. P. Singer, How Are We to Live. Ethics in an Age of Self-interest, New York 1997.

43 Wybrane świadectwa efektywnych altruistów zebrał i opublikował Singer w: P. Singer, The Most Good You Can Do..., dz. cyt., s. 97-104. 
organizacje otrzymały za jej pośrednictwem łącznie ok. $110 \mathrm{mln}$ USD $\left(28,2 \mathrm{mln}\right.$ w roku 2014, 17,5 mln w 2013, 8,6 w 2012) ${ }^{44}$. Wydaje się zatem, że efektywny altruizm jest nie tylko sposobem na poprawienie świata, lecz także drogą promocji rozsądku i umiarkowania w życiu publicznym. Zmiany w życiu osób, które inspirują się efektywnym altruizmem i weń włączają, skuteczne programy pomocowe zmieniające los biednych, nowe spojrzenie na organizacje dobroczynne, a wreszcie ogromna ilość środków, jakie dzięki tej idei zdołano przekierować, są również dowodem na to, że filozofia zmienia świat.

\section{Bibliografia}

Arystoetels, Etyka nikomachejska, tłum. D. Gromska, Warszawa 2008.

Bostrom N., Existential Risk Prevention as Global Priority, „Global Policy”4 (2013) issue 1, s. $15-31$.

Easterly W., The White Man's Burden. Why the West's Efforts to Aid the Rest Have Done so much Ill and so Little Good, New York 2006.

Givewell.org: http://www.givewell.org/about/impact (17.09.2016).

Leszczyński A., Eksperymenty na biednych. Polityczny, moralny i ekonomiczny spór o to, jak pomagać skutecznie, Warszawa 2016.

Lewandowski W., Przyszłość i odpowiedzialność. Problem uzasadnienia odpowiedzialności za przyszłe pokolenia we wspótczesnej etyce, Lublin 2015.

Liberman A., Effective Altruism and Christianity: Possibilities for Productive Collaboration, „Essays in Philosophy” 18 (2017) issue 1, s. 2-24.

MacAskill W., Doing Good Better. A Radical New Way to Make a Difference, London 2015. McMahan J., Philosophical Critiques of Effective Altruism, „The Philosophers' Magazine” 2016 issue 73, s. 92-99.

Mysona Byrska J., Odpowiedzialność konsumenta w świecie konsumpcji, w: Społeczna odpowiedzialność gospodarki. Perspektywa interdyscyplinarna, red. S. Fel, Lublin 2014, s. $149-158$

${ }^{44}$ Dane podaję za stroną Givewell.org: http://www.givewell.org/about/impact (17.09.2016). 
Mysona Byrska J., Wpływ wartości świata konsumpcji na sferę publiczną, „Filo-Sofija”

15 (2015) nr 29 (2/I): Z problemów współczesnej filozofii, s. 105-114.

Parfit D., Racje i osoby, tłum. W. M. Hensel, M. Warchala, Warszawa 2012.

Podręcznik efektywnego altruizmu, red. R. Carey, tłum. zbiorowe, Warszawa 2015.

Singer P., How Are We to Live. Ethics in an Age of Self-interest, New York 1997.

Singer P., The Most Good You Can Do. How Effective Altruism Is Changing Our Ideas About

Living Ethically, New Haven-London 2015.

Singer P., Why and how of Effective Altruism, https://www.ted.com/talks/peter_singer_

the_why_and_how_of_effective_altruism (17.09.2016).

Singer P., Życie które możesz ocalić, tłum. E. De Lazari, Warszawa 2011.

Słownik filozofii, red. J. Hartman, Kraków 2004.

Słownik języka polskiego PWN, http://sjp.pwn.pl/slowniki/rozs\%C4\%85dek.html (18.09.2016).

Synowiec J., Ethics for Everyday Heroes - from Utilitarianism to Effective Altruism, „Ethics

\& Bioethics" (in Central Europe) 6 (2016) issue 3-4, s. 147-156.

Żuradzki T., Granice troski o przyszłe pokolenia, „Diametros” 26 (2010), s. 206-225.

\section{Abstrakt}

\section{Umiarkowanie i rozsądek jako cnoty efektywnego altruisty}

W artykule została podjęta próba zrekonstruowania znaczenia cnót umiarkowania i rozsądku dla powstania ruchu filozoficzno-społecznego: Efektywnego Altruizmu i praktyki życia efektywnych altruistów w oparciu o publikacje jego kluczowych przedstawicieli: Petera Singera i Williama MacAskilla. W pierwszej części artykułu krótko referuję genezę i filozoficzne podstawy Efektywnego Altruizmu. Następnie staram się określić rolę rozsądku i umiarkowania w teoretycznych rozważaniach nad efektywnym altruizmem oraz w praktyce życia osób utożsamiających się z ruchem, w odniesieniu do rozumienia tych cnót zaprezentowanego przez Arystotelesa. Przedstawione rozumowanie wspiera tezę, że cnoty te mają kluczowe znaczenie dla praktyki codziennego życia efektywnych altruistów. Ostatnia część koncentruje się wokół spostrzeżenia, że Efektywny Altruizm może być w pewnym sensie alternatywą dla postawy konsumpcjonistycznej i przyczynić się do rehabilitacji tytułowych cnót w życiu publicznym. 


\section{Słowa klucze}

Efektywny Altruizm, umiarkowanie, rozsądek

\section{Abstract}

\section{Temperance and Prudence as Virtues of an Effective Altruist}

The aim of the paper is to analyze the importance of two virtues: temperance and prudence for genesis of the Effective Altruism and practice of life of effective altruists, on the basis of philosophical works of two main representatives of the idea and movement: Peter Singer and William MacAskill. In the first part of the paper genesis of the movement and it's basic assumptions are presented. Than, the paper focuses on the role of temperance and prudence in both theoretical reflection on effective altruism and practice of life of people identifying themselves withe the movement, with reference to Aristotle's understanding of the virtues. It is argued, that these virtues are crucial in the practice of life of an effective altruist. In the last part the paper focuses on the idea that Effective Altruism is in a sense an alternative to consumerism and can play a role in bringing mentioned virtues back into public life.

\section{Keywords}

Effective Altruism, temperance, prudence 